\title{
Histology of juvenile skin of Lepidosiren paradoxa Fitzinger, 1837 (Sarcopterygii, Dipnoi)
}

\author{
LUIS ALBERTO ROMANO ${ }^{1}$, ANDREA I.H. LÓPEZ ${ }^{1}$, JUAN RAFAEL BUITRAGO ${ }^{2}$ and VIRGÍNIA F. PEDROSA \\ ${ }^{1}$ Institute of the Oceanography, University Federal of the Rio Grande, Laboratory of the de Immunology and \\ Pathology of the Aquatic Organisms, Rua do Hotel, 2, Cassino, 96210-030 Rio Grande, RS, Brazil \\ ${ }^{2}$ University Federal of the Rio Grande, Laboratory of the Biochemistry Functional of Aquatic \\ Organisms, Rua do Hotel, 2, Cassino, 96210-030 Rio Grande, RS, Brazil
}

Manuscript received on July 20, 2019; accepted for publication on September 24, 2019

\begin{abstract}
How to cite: ROMANO LA, LÓPEZ AIH, BUITRAGO JR AND PEDROSA VF. 2019. Histology of juvenile skin of Lepidosiren paradoxa Fitzinger, 1837 (Sarcopterygii, Dipnoi). An Acad Bras Cienc 91: e20190822. DOI 10.1590/0001-3765201920190822.
\end{abstract}

\begin{abstract}
The skin of three juvenile Lepidosiren paradoxa specimens was examined. The epidermis was composed of a polystratified epithelium resting on a basement membrane, including mucus-secreting cells, and a cuticle of mucopolysaccharides on the surface. Two types of skin receptors, electroreceptors and mechanoreceptors, were found; the first type was located in the dermoepidermal junction, and the second type was completely intraepiderma. The skin structure of these fish, suggests the possibility of the skin participating in the breath.
\end{abstract}

Key words: electroreceptors, lungfish, mechanoreceptors, Paraná River basin, pirambóia.

\section{INTRODUCTION}

The South American Lungfish (Lepidosiren paradoxa) is found in the marshes and slow waters of the Amazon, Paraguay Basin and Paraná River in South America (Vallone 2017). As a remarkable obligate air breather, he is also the only recent member of the family, Lepidosirenidae (Froese and Pauly 2014).

Juvenile lungfish feed on the larvae of insects and snails, while the adults are omnivores, adding algae and shrimp to their diets and crushing them with their highly mineralized dental plates. The usual habitats of the fish disappear during the dry season; during this time, they hide in the mud and make a chamber approximately $30-50 \mathrm{~cm}$ beneath

Correspondence to: Luis Alberto Romano

E-mail: luisalbertoromano0@gmail.com

ORCid: https://orcid.org/0000-0003-3144-3579 the mud surface, leaving some holes to the surface for air to enter. The skin has important functions during this aestivation, and a layer of mucus is produced to seal in moisture and slow down its metabolism as well as to participate in respiration (Bruton 1998).

The objective of this work is to describe the skin of L. paradoxa juveniles, as well as to demonstrate characteristics of adaptation of the species to the environment with the presence of electro and mechanoreceptors, which are necessary for their survival.

\section{MATERIALS AND METHODS}

Three L. paradoxa juveniles were captured by fishermen in a sector with mud and scarce water where they were buried in Esteros del Ibera in the province of Corrientes, Argentina. The lengths 
of the specimens were 110, 107 and $125 \mathrm{~mm}$. The specimens were anaesthetized with $0.5 \%$ benzocaine (Sigma-Aldrich) for approximately 30 minutes according to De Moraes et al. (2005). Transverse skin sections were obtained from the dorsal and dorsocephalic region, dorsolateral and abdominal region, fixed in $10 \%$ formalin, and embedded in Paraplast. The histological sections were stained with haematoxylin and eosin, periodic acid Schiff (PAS), Kuhn blue and Cajal gold sublimate modified for sections embedded in Paraplast and identified histological structures according to Mokhtar (2017) (Naoumenko and Feigin 1961).

\section{RESULTS}

In the histological sections, we observed the classic layers that form the skin of fish: the epidermis, the stratum spongiosum and stratum compactum of the dermis, the hypodermis and the subcutaneous muscle (Figure 1).

The epidermis was composed of a polystratified epithelium of between 4 and 5 layers of cells, and the entire epidermis rested on a basement membrane (BM) (Figure 2).

The epidermis was composed of several cell types. The basal cells are totipotent cells that generate all other cells, and these cells can become irregular. Mucus-secreting cells were present in the Malpighian stratum. As juvenile animals were observed, mucus-secreting cells showed high cellular activity; these cells were hyperchromatic with several mitotic cells (Figure 3). On the surface, a PAS-positive cuticle was observed, possibly composed of mucopolysaccharides (Figure 4). The epidermis rested on a BM that separated it from the stratum spongiosum of the dermis in which there was abundant melanin belonging to melanophores. Melanin was also observed scattered throughout the thickness of the epidermis. Melanophores stained with Cajal gold sublimate showed

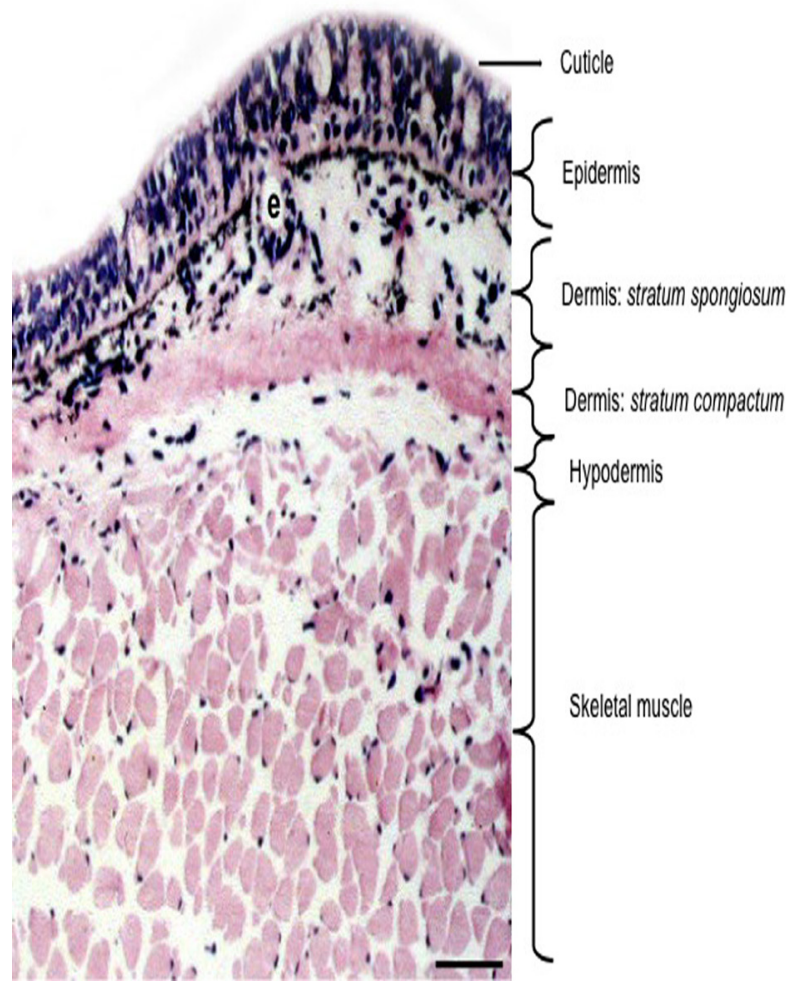

Figure 1 - Skin of dorsolateral region of L. paradoxa with its differentiated skin layers. A tubule of an electroreceptor is visible in the dermoepidermal junction (e). H-E. Bar: $200 \mu \mathrm{m}$.

irregular prolongations (Figure 5). In the stratum compactum of the dermis, we observed abundant collagen and elastic fibres and vascular structures. The hypodermis was very thin, with a few isolated vascular capillaries

Mechanoreceptors were located in the epidermis, and electroreceptors were observed within the dermis near the epidermis. The mechanoreceptors comprised a group of columnar cells derived from the epithelium, with a central neuroepithelial cell from which stereocilia exited to the surface; modified columnar epithelial cells surrounded and supported the mass of the sensory cells (Figure 6).

Electroreceptors were present in the epidermis and superficial areas of the dermis and consisted of a double layer of cuboidal cells forming a hollow bulb located below the collagen of the dermoepidermal junction (Figure 7). The cells lining the bulb had 


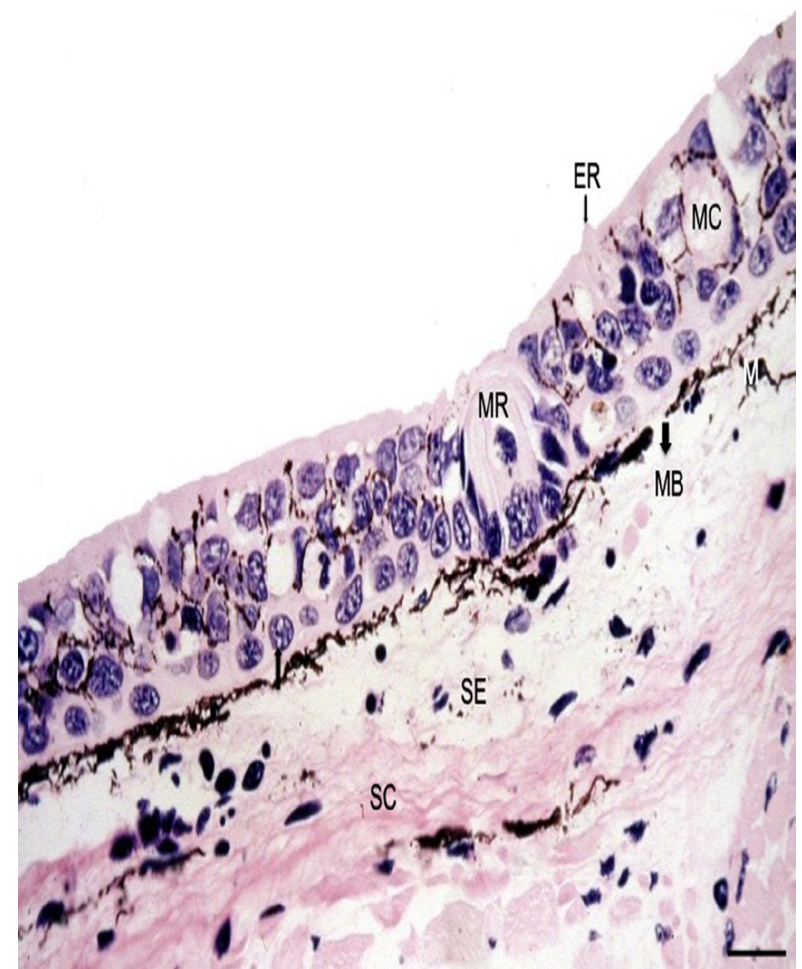

Figure 2 - Skin of dorsocephalic region of L. paradoxa. Epidermal basal cells (arrow) with an underlying basement membrane (BM arrow) and mucus-secreting (MC) cells. A mechanoreceptor (MR) is visible at the external end of the electroreceptor (ER). The stratum spongiosum and compactum (SE-SC) of the dermis with melanophores (M) are also visible. H-E. Bar: $100 \mu \mathrm{m}$.

tiny projections from the surface, and some of the cells showed evidence of cell division, which was uncommon elsewhere in the epidermal and dermal tissues. A narrow duct, lined by a single layer of epithelial cells, extended from the base to the surface of the epithelium where it opened like a small circular hole surrounded by small papillae.

\section{DISCUSSION}

The structure of the skin of L. paradoxa and other lungfish has been described by several authors (Coelho and Sawaya 1972, Imaki and Chavin 1975a, b). The importance of skin structure in the physiology of these fish is significant; the skin of all teleosts is the primary protective barrier against external pathogens, and mucus production plays an

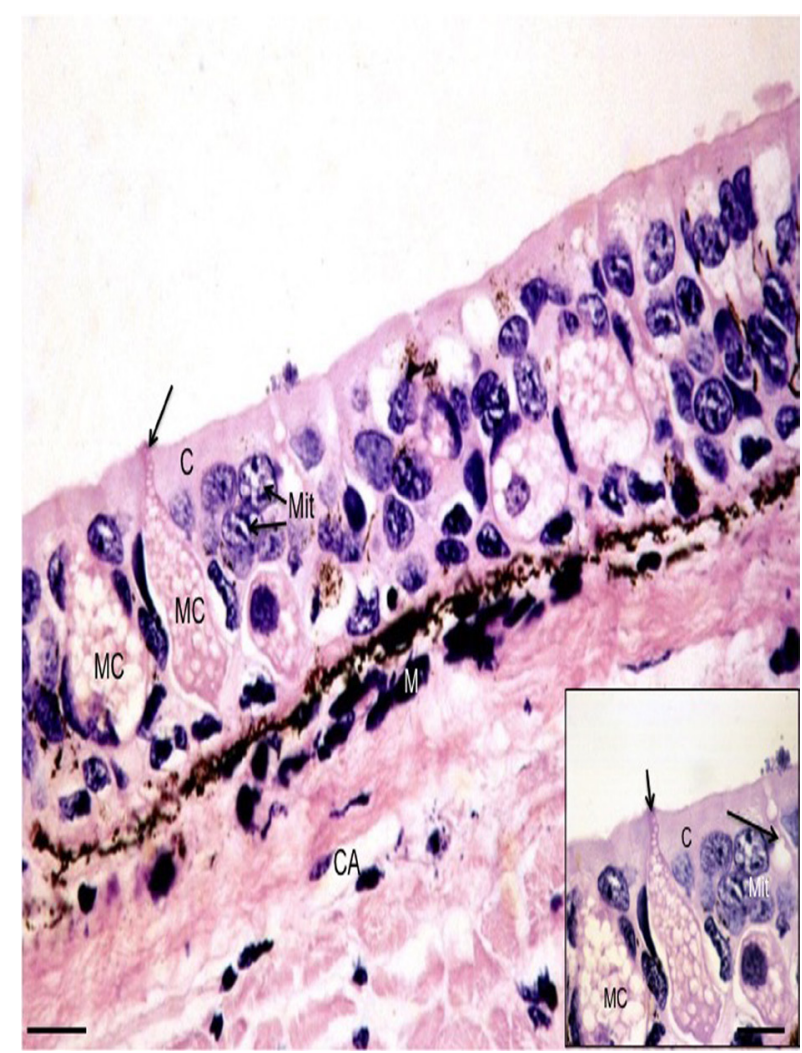

Figure 3 - Skin of dorsocephalic region of L. paradoxa. Epidermis with abundant mucus-secreting (MC) cells. The mucus is released at the surface, forming the cuticle (C). Several mitotic (Mit) cells are visible. In the dermis, melanophores (M) and capillaries (CA) are visible. H-E. Bar: $50 \mu \mathrm{m}$. Insert: mucus-secreting (MC) cells releasing mucus to the outside (short arrow), forming the cuticle (C). There is a tubule of an electroreceptor (long arrow), and mitosis (Mit) can be observed. H-E. Bar: $20 \mu \mathrm{m}$.

important role in the non-specific immune response (Heimroth et al. 2018, Xu et al. 2013). Moreover, since L. paradoxa is a lungfish, the mechanisms and tissues involved in the respiratory process are diverse, and the skin plays a very important role; in this sense, lungfish skin is similar to that of amphibians (Hughes 1976).

The skin of the snout and lips in the living Neoceratodus forsteri is soft, and free of scales at all stages of the life cycle. In external view, the skin of the snout is pitted, with perforations of various sizes, for goblet cells and sense organs, and apart 


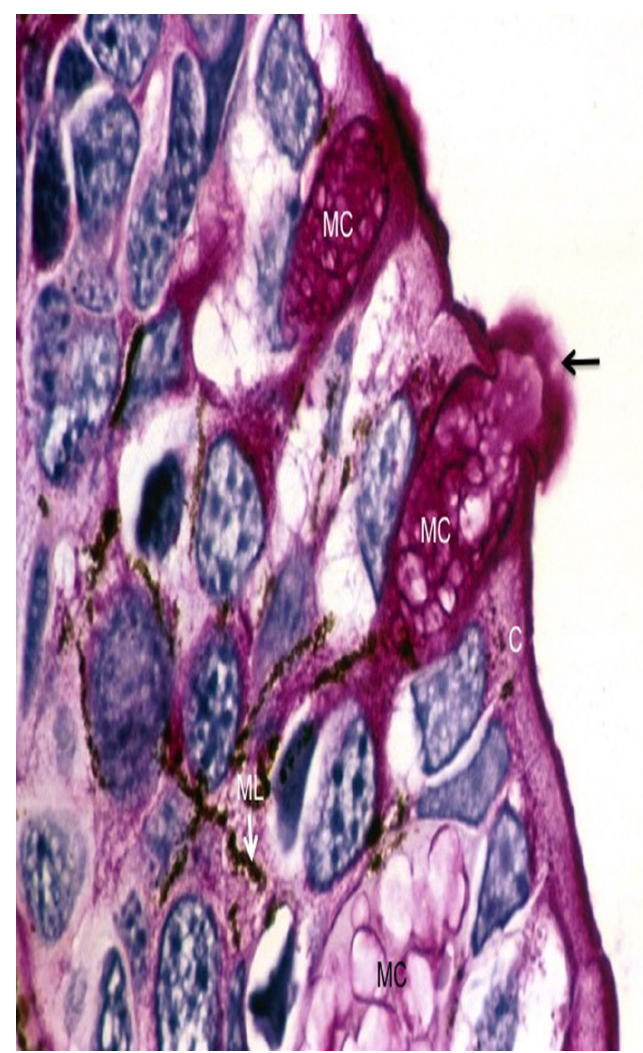

Figure 4 - Skin of dorsal region of L. paradoxa. Epidermis with PAS-positive mucus-secreting (MC) cells. One of these cells is releasing the mucus at the surface (arrow), contributing to the formation of the cuticle (C). Melanina (ML). PAS. Bar: $20 \mu \mathrm{m}$.

from this, individual epithelial cells are visible in surface view (Kemp 2012).

The epidermis in these juvenile animals showed intense cellular activity, such that almost all of their cells had hyperchromatic nuclei with abundant mitosis. Such cellular activity has not been previously reported, even in studies on the juvenile skin of both L. paradoxa and Neoceratodus forsteri (Imaki and Chavin 1975a, b). This high cellular activity is expected in all vertebrates since the epidermis belongs to the class of labile tissues with a high rate of cell renewal. In addition, in the case of juvenile animals, the average life span of cells is shorter (Gartner 2017). Johansen and Lenfant (1967) have observed blood capillaries in the epidermis, while we observed capillaries in the dermis only. The epithelium structure does not

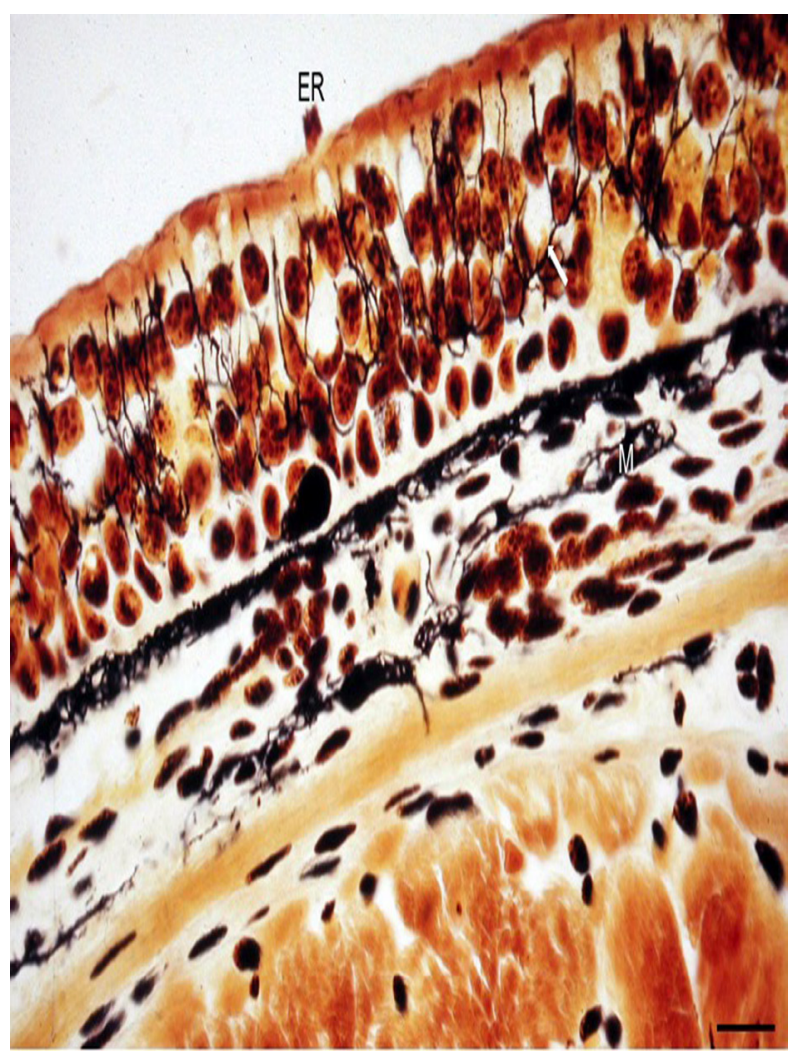

Figure 5 - Skin of abdominal region. of $L$. paradoxa Epidermis with marked cellular activity. Melanin can be observed in the epidermis (arrow) at the surface of an electroreceptor (ER). In the dermis, melanophores with "dendritic" extensions (M) can be observed. Cajal gold sublimate. Bar: $50 \mu \mathrm{m}$.

contain capillaries; instead, it is nourished by the blood capillaries of subepithelial connective tissue, in this case, the dermis (Gartner 2017).

PAS-positive mucus-secreting cells were predominantly found in the epidermis. These cells were loaded with mucus, which they released at the surface, generating a mucosal surface over the entire body of the fish. Although the mucus should help with swimming, it may be more helpful when the animals exit the caves that they make in the mud; when the mud dries, the mucus provides lubrication to allow mobility. In addition, mucus is rich in lysozyme that acts as a broad spectrum bactericide (Romano 2010).

The mechanoreceptors are part of the acousticlateral system. These receptors collect mechanical signals in the water and have both afferent and 


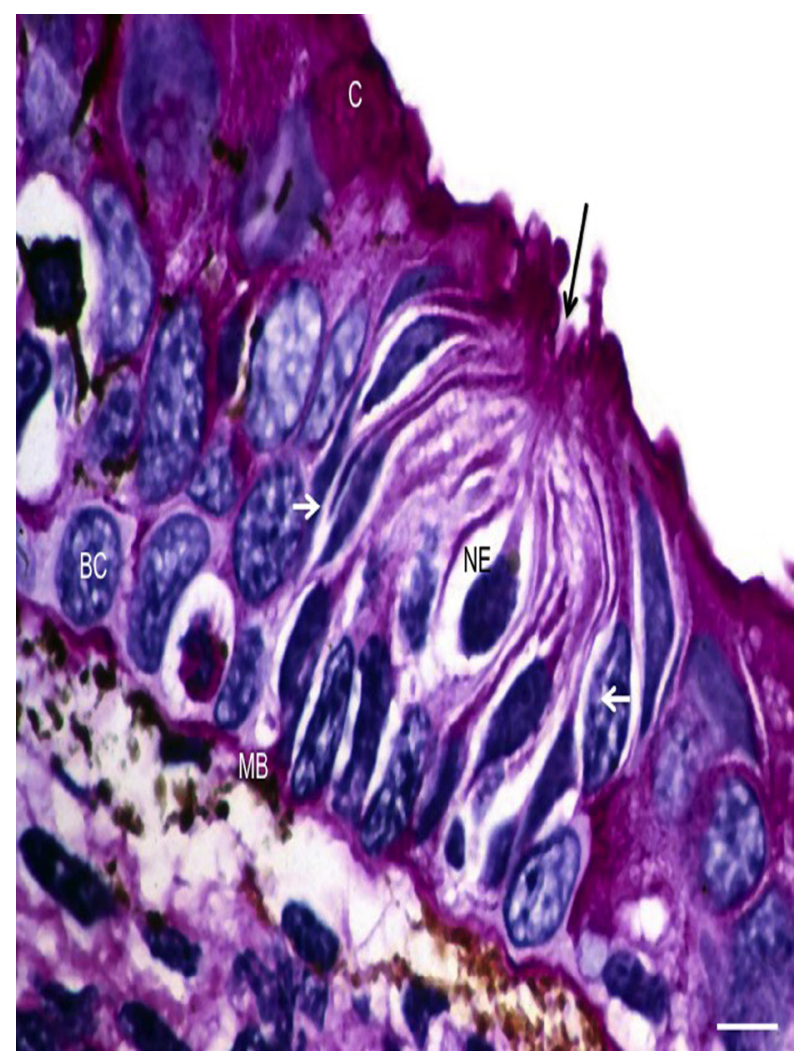

Figure 6 - Skin of dorsocephalic region of L. paradoxa. A mechanoreceptor that occupies the entire thickness of the epidermis. The basal part rests on the basal membrane (MB). The neuroepithelial central cell (NE) is surrounded by support cells (short arrows) and the basal cells of the Malpighian stratum (BC), and the neuropil reaches the surface (long arrow) through the cuticle (C). PAS. Bar: $20 \mu \mathrm{m}$.

efferent innervation. The electroreceptors are small, confined to the superficial layers of the dermis or epidermis, and exhibit single innervation (Northcutt 1986). These receptors are sensitive to weak electrical currents in the water possibly emitted by prey animals (Roth 1973, Roth and Tscharntke 1976, Bullock et al. 1983, Kramer 1996, Collin and Whitehead 2004).

The skin is recognized as a secondary respiratory tissue in several species (Urbina and Meredith 2014), and in lungfish, epidermal mucus is directly related to respiratory physiology (Heimroth et al. 2018).

This study provides a characterization of the skin of a sarcopterygian fish, the juvenile

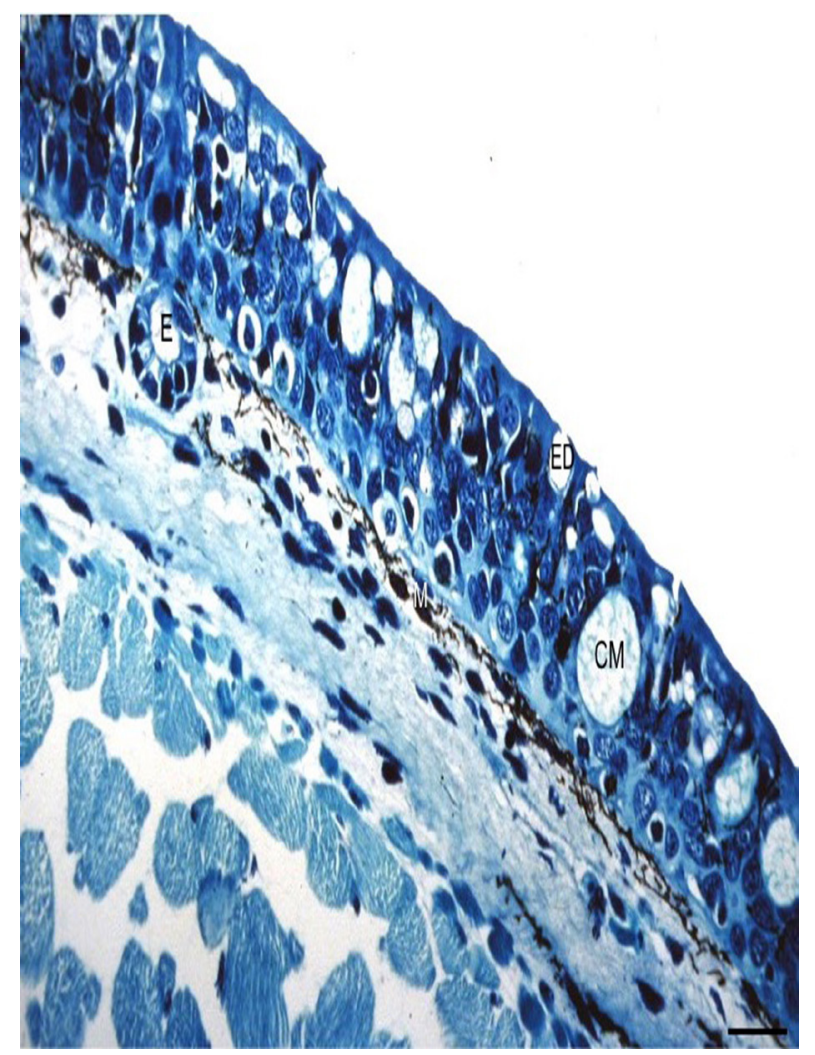

Figure 7 - Skin of dorsal region of L. paradoxa. At the dermoepidermal border, a tubule of an electroreceptor with a double layer of cuboidal cells (e) is visible; in the epidermis, mucus-secreting (MC) cells are visible, along with the duct of an electroreceptor (ED). Kuhn blue. Bar: $100 \mu \mathrm{m}$.

South American lungfish. In the present study, the structure of the skin of these fish, together with the identification of electroreceptors and mechanoreceptors, was elucidated.

According to Zena et al. (2017), the skin of Lepidosiren paradoxa actively exchanges $\mathrm{CO}_{2}$ through the skin. Therefore, studying the structure of this organ that seems important in the appearance of terrestrial respiration is essential.

\section{ACKNOWLEDGMENTS}

The authors are grateful for the financial support provided by the Coordenação de Aperfeiçoamento de Pessoal de Nível Superior (CAPES; grant number ED09/2009). L. Romano is a research fellow of the Conselho Nacional de Desenvolvimento Científico 
e Tecnológico (CNPq). The authors declare no conflict of interest with respect to the research, authorship and publication of this article.

\section{AUTHOR CONTRIBUTIONS}

Luis Alberto Romano in the animal acquisition, necropsy and slide analysis. Virgínia Fonseca Pedrosa in the histological processing, necropsy and follow-up analysis. Andrea Idelette Hernández López and Juan Rafael Buitrago in the histological processing and slide staining.

\section{REFERENCES}

BRUTON MN. 1998. Encyclopedia of Fishes, Paxton JR and Eschmeyer WN (Eds), San Diego: Academic Press. ISBN 0-12-547665-5.

BULLOCK TH, BODZNICK DA AND NORTHCUTT RG. 1983. The phylogenetic distribution of electroreception, evidence for convergent evolution of a primitive vertebrate sense modality. Brain Res Rev 6: 25-46.

COELHO LMPS AND SAWAYA P. 1972. Fisioecologia de Tambaky M'Boya-Lepidosiren paradoxa (Fitizinger) da Amazônia (Peixe-Dipnóico). Bol Zool Biol Mar 29: 65118.

COLLIN SP AND WHITEHEAD D. 2004. The functional roles of passive electroreception in non-electric fishes. Anim Biol 54: 1-25.

DE MORAES MF, HOLLER S, DA COSTA OT, GLASS ML, FERNANDES MN AND PERRY SF. 2005. Morphometric comparison of the respiratory organs in the South American lungfish Lepidosiren paradoxa (Dipnoi). Physio Biochem Zool 78: 546-559.

FROESE R AND PAULY D. 2014. "Lepidosiren paradoxa" in FishBase. April 2014 version.

GARTNER LP. 2017. Textbook of Histology, $4^{\text {th }}$ ed., Elsevier Philadelphia, 99-125, 658 p.

HEIMROTH RD, CASADEI E AND SALINAS I. 2018. Effects of experimental Terrestrialization on the skin Mucus Proteome of african lungfish (Protopterus dolloi). Front Immunol 9: 1259-1269.

HUGHES GM. 1976. Respiration of Amphibious Vertebrates, p. 312-118, 402 p. London, New York, San Francisco: Academic Press.
IMAKI H AND CHAVIN W. 1975a. Ultrastructure of the Integumental Melanophores of the Australian Lungfish, Neoceratodus forsteri. Cell Tissue Res 158: 363-373.

IMAKI H AND CHAVIN W. 1975b. Ultrastructure of the Integumental Melanophores of the South American Lungfish (Lepidosiren paradoxa) and the African Lungfish (Protopterus sp.). Cell Tissue Res 158: 375-389.

JOHANSEN KAND LENFANT C. 1967. Respiratory function in the South American lungfish, Lepidosiren paradoxa (Fitz).J Exp Biol 46: 205-218.

KEMP A. 2012. Formation and structure of scales in the Australian lungfish, Neoceratodus forsteri. J Morphol 273: 530-540.

KRAMER B. 1996. Electroreception and communication in Fishes. Progr Zool 42: 1-119.

MOKHTAR DM. 2017. Fish Histology. From Cells to Organs, p. 102-103, 246 p. Apple Academic Press Inc.

NAOUMENKO J AND FEIGIN I. 1961. A Modification for Paraffin Sections of the Cajal Gold-Sublimate Stain for Astrocytes. J Neuropathol Exp Neurol 20: 602-604.

NORTHCUTT RG. 1986. Electroreception in non-teleost bony fishes. In: Bullock TH and Heiligenberg W (Eds), Electroreception. John Wiley and Sons, New York, 722 p.

ROMANO LA. 2010. El sistema Imune de los Peces. In: SilvaSouza AT, Perez Lizama MA and Takemoto RM (Eds), Patologia Sanidade de Organismos Aquáticos, p. 243-274.

ROTH A. 1973. Electroreceptors in Brachiopterygii and Dipnoi. Die Naturwissenschaften 60: 106.

ROTH A AND TSCHARNTKE H. 1976. Ultra-structure of the ampullary electroreceptors in lungfish and Brachiopterygii. Cell Tissue Res 173: 95-108.

URBINA M AND MEREDITH A. 2014. The importance of cutaneous gas exchange during aerial and aquatic respiration in galaxiids. J Fish Biol 84(3): 1-15.

VALLONE ER. 2017. New locality for Lepidosiren paradoxa Fitzinger, 1837 (Dipnoi: Lepidosirenidae) in Argentina. Check List 13: 1-4.

XU Z, PARRA D, GÓMEZ D, SALINAS I, ZHANG Y, VON GERSDORFF JØRGENSEN L, HEINECKE RD, BUCHMANN K, LAPATRA S AND SUNYER JO. 2013. Teleost skin, an ancient mucosal surface that elicits gut-like immune responses. Proc Natl Acad Sci 110(32): 13097-13102.

ZENA LA, BICEGO KC, DA SILVA GSF, GIUSTI H, GLASS ML AND SANCHEZ AP. 2017. Acute effects of temperature and hypercarbia on cutaneous and branchial gas exchange in the South American lungfish, Lepidosiren paradoxa. J Thermal Biol 63: 112-118. 